(C) 2016

Поздняков В. В., кандидат биологических наук, Харченко Ю. В., кандидат сельскохозяйственных наук, Харченко Л. Я., научный сотрудник

Устимовская опытная станция растениеводства

Анцыферова О. В., младший научный сотрудник

Институт растениеводства им. В. Я. Юрьева НААН

\title{
СОЗДАНИЕ ГИБРИДОВ СВЕРХСАХАРНОЙ КУКУРУЗЫ С ВЫСОКИМ УРОВНЕМ АНТИОКСИДАНТНОЙ АКТИВНОСТИ С ИСПОЛЬЗОВАНИЕМ ТЕСТ-СИСТЕМЫ НА ОСНОВЕ СТАБИЛЬНОГО РАДИКАЛА ФРРН
}

\section{Рецензент - кандидат сельскохозяйственных наук О. В. Тригуб}

\begin{abstract}
Гібриди иукрової і супериукрової кукурудзи є хорошою сировиною для виробництва функиіональних харчових продуктів, зокрема дієтичного та дитячого харчування. Важливими показниками високої якості изих продуктів є підвищений вміст білка і иүінного масла, незначна кількість погано засвоюваного кукурудзяного крохмалю і високий вміст антиоксидантів, а також відмінні смакові якості. У роботі представлені дані щзодо оцінки антиоксидантної активності великої групи нових перспективних гібридів супериукрової кукурудзи середньостиглої групи, створених з метою отримання цінних джерел сировини для консервної промисловості. Значення показника загальної антиоксидантної активності варіювали в широкому інтервалі значень (від 31,8\% до 60,4\%, 568,4-1008 мкг/2 насіння), щзо вказує на перспективність використання циього важливого біохімічного параметра в селекції супериукрової кукурудзи на якість.
\end{abstract}

Ключевые слова: овочная (сахарная) кукуруза, $s u_{1}, \mathrm{se}$, антиоксидантная активность, DPPH, гибриды, функциональные продукты питания.

Постановка проблемы. Традиционно показателями высокого качества гибридов овощной кукурузы (сахарной и сверхсахарной кукурузы) являются высокое содержание белков, ценного кукурузного масла и низкое содержание крахмала. Антиоксидантным свойствам этой диетической продукции практически не уделялось должного внимания. Однако тенденции развития современного рынка высококачественных продуктов, в том числе и функциональных продуктов питания, заставляют тщательно контролировать этот важный показатель при селекции новых сортов и гибридов овощной кукурузы. Это позволит специалистам в области здорового и диетического питания оценить возможность использования продуктов переработки овощной кукурузы в специализированных диетах для улучшения здоровья человека. Среди многочисленных методик и тест-систем оценки общей антиоксидантной активности продуктов питания была выбрана достаточно простая, надежная и распространенная тест-система с использованием стабильного радикала DPPH. Эта методика была адаптирована для оценки общей антиоксидантной активности в зерне кукурузы полной спелости, которое является сырьем для производства очень большого количества продуктов питания и зернофуражных смесей различного направления использования.

Анализ исследований и публикаций, в которых начато решение проблемы. Разнообразное использование продуктов, получаемых из кукурузы, является причиной того, что перерабатывающая промышленность ставит перед селекционерами особые требования к качеству сырья в зависимости от конечного продукта переработки. Эти требования зачастую бывают противоположными и взаимоисключающими. В связи с этим селекционеры ведут свою работу в разных направлениях относительно улучшения качества кукурузы, создавая специализированные гибриды для конкретных направлений использования.

Традиционная селекция сахарной кукурузы основывается на использовании биохимических эффектов мутантного гена $\mathrm{su}_{1}$, вызывающего частичную депрессию синтеза крахмала и увеличивающего в семенах технической спелости содержание свободных углеводов и водорастворимых полисахаридов. Такая модификация углеводного комплекса обеспечивает высокие потребительские качества сахарной кукурузы и возможности ее использования в качестве овощной культуры. В последние годы широкое распространение получили гибриды сверхсахарной кукурузы, основанные на использовании мутаций $\mathrm{sh}_{2}$ и модификатора гена $\mathrm{su}_{1}-\mathrm{se}$. Именно комбина- 


\section{СІЛЬСЬКЕ ГОСПОДАРСТВО. РОСЛИННИЦТВО}

ция мутантного гена $\mathrm{su}_{1}$ с геном-модификатором se обеспечивает наилучший углеводный состав зерна в технической спелости и содержание углеводов достигает 11-12\%.

Важными показателями высокого качества гибридов этого типа являются повышенное содержание белка и ценного масла, незначительное количество плохо усваиваемого кукурузного крахмала и высокое содержание антиоксидантов, а также отменные вкусовые качества. И если содержанию белка, углеводов и масла селекционеры уделяли постоянное внимание на протяжении нескольких десятилетий, то контроль высокой общей антиоксидантной активности практически не осуществлялся. Однако высокие требования к качеству сырья в связи с развитием отрасли производства функциональных продуктов питания, в которых регламентируется высокое, генетически обусловленное содержание биологически ценных питательных компонентов (белки, витамины, микроэлементы, незаменимые аминокислоты, жирные кислоты - особенно олеиновая и линоленовая, а также полифенолы), вынуждают к поиску источников высокой антиоксидантной активности среди различных традиционных и новых форм растений.

Этиологию многих хронических заболеваний человека и возрастные изменения при старении связывают с разрушительным действием свободных радикалов, которые могут нарушать нативную структуру важных природных биомолекул, таких как белки, ДНК и липиды, и вследствие этого инициировать хронические болезни и способствовать их развитию [5]. В научной литературе широко обсуждается способность большого количества биоактивных компонентов (химических соединений) растений и экстрактов семян играть роль антиоксидантных профилактических агентов, способствующих нормализации здоровья и лечению болезней [8].

По определению, антиоксидантом может считаться любое химическое соединение, способное в незначительной концентрации, в сравнении с защищаемым субстратом, замедлять или предотвращать окисление многих важных компонентов клеток, включая липиды (в том числе и полиненасыщенные жирные кислоты), белки, углеводы и ДНК [18]. К антиоксидантам также относят:

- кислотные компоненты (включая фенолы), которые могут быть использованы в пищу или быть включены в косметические и фармацевтические препараты и способные легко отдавать электроны или атомы водорода перекисным радикалам, разрывая цепные реакции перекисного окисления;
- химические вещества, способные эффективно и быстро регенерировать фенольные соединения;

- соединения, способные эффективно хелатировать ионы прооксидантных переходных металлов.

Это обобщенное определение не привязывает антиоксидантную активность к какой-то специфической группе химических соединений или к определенному механизму действия. Концепция антиоксидантов позволяет относить к ним большое количество самых разнообразных соединений, включая антиоксидантные ферменты, железо-связывающие и транспортные белки, а также компоненты, способные осуществлять передачу сигнальной информации через клеточные мембраны и экспрессию генов.

В организме животных и растений присутствует несколько различных механизмов нейтрализации активных свободных радикалов для поддержания баланса между антиоксидантами и оксидантами. При определенных условиях защитные антиоксидантные механизмы организма могут быть преодолены и избыток свободных радикалов приведет к развитию оксидативного стресса. Было высказано предположение, что различные классы компонентов питания могут снижать риск возникновения некоторых видов злокачественных опухолей, особенно рака кишечника, и было получено несколько результатов, указывающих на то, что потребление определенных продуктов приводит к снижению оксидативных разрушений в биомаркерах. Следовательно, организмы животных и человека нуждаются в достаточных количествах внешних источников антиоксидантов для поддержания окислительного баланса и предотвращения оксидативного стресса и сопровождающих его хронических заболеваний [7, 9, 17].

С целью изучения связи между пищевыми факторами и возможностью профилактики возникновения хронических заболеваний, а также получения объективной информации для селекции ценных пищевых источников антиоксидантов, в последние годы широко используют аналитические методы измерения общей антиоксидантной активности для всех видов растительной продукции (продукты питания, лекарственные, эфиромасличные, пряно-ароматические культуры, сырье для изготовления напитков - чай, кофе, мате и пр.). В литературе постоянно появляются сведения о создании новых методов, позволяющих исследовать различные механизмы действия антиоксидантов в опытах in vivo и в модельных тест-системах in vitro $[4,16,21]$. В литературе в 


\section{СІЛЬСЬКЕ ГОСПОДАРСТВО. РОСЛИННИЦТВО}

основном представлена информация об антиоксидантной активности водорастворимых экстрактов пищевых продуктов. Антиоксидантная активность in vivo и в продуктах питания может осуществляться путем ингибирования активных форм кислорода или прямой нейтрализацией свободных радикалов.

Поскольку антиоксиданты нейтрализуют свободные радикалы и оксиданты, их потребление с пищей может способствовать профилактике многих хронических заболеваний. Среди этих химических соединений растительного происхождения, получивших название фитохимических компонентов, наиболее широко представлены вторичные метаболиты фенольной природы (полифенолы), обладающие высоким окислительно-восстановительным потенциалом [11, 20], хотя гораздо правильнее было бы ограничивать этот термин только более комплексными молекулами, известными под общим названием таннины [22]. Вторичные метаболиты отличаются от первичных или основных метаболитов (углеводов, белков, аминокислот, нуклеиновых кислот и липидов) тем, что они не участвуют в базовых метаболических циклах роста и развития растений, однако они незаменимы для многих важных функциональных аспектов жизни растений [16]. Вторичные метаболиты известны давно, однако их ценность обнаружилась относительно недавно. Они выполняют структурную функцию в различных опорных и защитных тканях, участвуют в защитных системах растений от поедания травоядными животными и патогенов (вирусы, бактерии, микоплазма и грибковые заболевания), выполняют сигнальные функции, например, принимают участие во взаимодействиях растений с факторами окружающей среды, выполняя часть функций адаптивной стратегии растений.

Полифенолы представляют собой очень гетерогенную группу соединений, часть из них распространена во всех растениях, тогда как некоторые представители встречаются только в тех или иных семействах или родах, или в отдельных органах растений вместе с терпеноидами и изопреноидами (каротеноиды, монотерпены, фитостеролы, сквален, эфирные масла), серосодержащими компонентами (глюкозинолаты сем. крестоцветные), азотсодержащие соединения (алкалоиды и гетероциклические ароматические соединения) [9, 10].

Основное внимание в литературе было направлено на фенольные соединения фруктов, овощей и напитков (вина, чая, кофе), однако многие из этих соединений присущи также зерновым куль- турам [8, 14]. В последние годы все больше уделяется внимание питательным ценностям полифенолов, поскольку они могут играть важную роль в профилактике многих распространенных хронических заболеваний и в целом способны оказывать благоприятный эффект на здоровье человека [12].

Способность фенольных компонентов нейтрализовать свободные радикалы зависит от их структуры: в первую очередь от способности переносить атомы водорода ароматической группы на свободные радикалы или электроны ароматического компонента, восстанавливать неспаренные электроны сопряженной $\pi$-системы [19].

По оценкам специалистов необходимо с пищей ежедневно принимать примерно 1 г полифенолов, что значительно выше обоснованных доз других необходимых в пище компонентов, таких как каротиноиды, витамин Е и витамин С (5, 12 и 90 мг/сутки соответственно). Следовательно, полифенолы являются основными антиоксидантами в пище человека, т.е. их потребление примерно в 10 раз больше, чем потребление витамина С и в 100 раз больше, чем витамина $\mathrm{E}$ [24]. Поэтому регулярное потребление фруктов, овощей, семян и продуктов, произведенных из них, а также напитков, содержащих полифенолы в больших количествах, рекомендовано для улучшения здоровья человека. Высокое содержание природных антиоксидантов в продуктах питания и напитках повышает срок их хранения и предотвращает ухудшение аромата и изменение естественной окраски продуктов при длительном хранении. Высокие антиоксидантные свойства являются своеобразной торговой маркой полифенолов для их использования косметической и фармацевтической промышленностями, в изготовлении функциональных продуктов питания и пищевых биодобавок [3].

Нейтрализация стабильного окрашенного радикала 1,1-diphenyl-2-picrylhydrazylradical (DPPH) в органической среде широко используется как тест-система оценки антирадикальной активности растительных образцов. Антиоксиданты, экстрагируемые 80 \% водным раствором этанола или метанола и способные нейтрализовать свободные радикалы, обесцвечивают раствор DPPH, a спектрофотометрирование при 517 нм позволяет количественно оценивать антирадикальную активность экстрактов семян или продуктов питания. Эта тест-система является недорогой, хорошо стандартизуется и удобна для проведения скрининга большого количества образцов (например, промежуточных селекционных форм 


\section{СІЛЬСЬКЕ ГОСПОДАРСТВО. РОСЛИННИЦТВО}

или отборов многочисленных коллекционных образцов). Снижение интенсивности окраски прямопропорционально содержанию антиоксидантов в пробе.

Цель исследований - выделения ценных источников высокой антиоксидантной активности кукурузы, как овощной культуры, для практического использования в гетерозисной селекции.

Задача исследований - оценка новых перспективных гибридов сверхсахарной кукурузы селекции Института растениеводства им. В. Я. Юрьева и Устимовской опытной станции растениеводства по уровню антиоксидантной активности с использованием тест-системы на основе стабильного радикала DPPH, а также по комплексу признаков продуктивности, которые в совокупности отражают селекционную ценность гибридов.

Материалы и методы исследований. В данном исследовании были проанализированы 59 перспективных гибридов сверхсахарной кукурузы селекции Института растениеводства им. В. Я. Юрьева и Устимовской опытной станции растениеводства. Полевые наблюдения проводились в Устимовской опытной станции растениеводства, в центральной части левобережной Украины, на границе лесостепной и степной зон. Предшественник - чистый пар. Почва - среднесуглинистый, малогумусный, распыленный чернозем.

При проведении исследований и оценке гибридов руководствовались соответствующими методиками $[1,2]$ с учетом специфики подвида сахарной кукурузы. Образцы высевались на участках площадью 9,8 м² с расположением растений по схеме 70х70 см (2 растения в гнезде). Образцы были оценены по 15 хозяйственно-ценным признакам.

Для анализа использовали материал исключительно от контролируемого опыления. Образцы семян кукурузы размалывали на лабораторной мельнице по 0,5 г муки в виале с герметично завинчивающимися крышечками, заливали 4,5 мл 80 \% этанола и экстрагировали 20 часов при комнатной температуре в темноте. Пробы центрифугировали $(10$ мин при $3000 \times$ g) на центрифуге ОПН-3.

Определение антирадикальной активности (как способности нейтрализации свободных радикалов) проводили с использованием стабильного радикала (DPPH) согласно методу, описанному в статье [6] с небольшими изменениями. Готовили спиртовой раствор радикала растворением 22 мг DPPH в 400 мл 80 \% этанола на магнитной мешалке в условиях рассеянного света, крупинки нерастворившегося красителя расти- рали пестиком в фарфоровой ступке. Раствор фильтровали и хранили в течение суток.

K 3,5 мл рабочего раствора DPPH добавляли 0,2 мл экстракта семян при комнатной температуре, перемешивали, ставили на 2 часа в темное место и регистрировали изменение светопоглощения полученной смеси. В контрольном образце к 3,5 мл рабочего раствора DPPH добавляют 0,2 мл 80 \% этанола. Способность образца нейтрализовать стабильный свободный радикал DPPH (антиоксидантная активность - АA) (\%) определяется как:

$$
\mathrm{AA}(\%)=100 \times(\mathrm{A}-\mathrm{B}) / \mathrm{A}
$$

где $\mathrm{A}$ - светопоглощение контрольного образца, В - светопоглощение опытного образца (через 2 часа после смешивания с рабочим раствором радикала (DPPH). Однако этот показатель в значительной мере относителен и зависит от условий проведения эксперимента, концентрации DPPH, соотношения объемов раствора стабильного радикала и экстрактов семян, температуры и других факторов проведения анализа. Поэтому рекомендовано полученные данные выражать в единицах эквивалента стандарта антиоксидантной активности, в качестве которого чаще всего используют аскорбиновую кислоту, «Тролакс» (синтетический водорастворимый аналог «Токоферола»), галловую кислоту и прочее.

В наших исследованиях в качестве стандарта антиоксидантной активности используется хлорогеновая кислота и антиоксидантная активность выражается в мкг хлорогеновой кислоты на 1 г семян образца в соответствии с данными калибровочного графика.

Результаты исследований. В Институте растениеводства им. В. Я. Юрьева селекция сахарной и сверхсахарной кукурузы велась на протяжении последних двадцати лет. Были созданы и внесены в Реестр сортов Украины гибриды и сорта, характеризующиеся высокими вкусовыми качествами, хорошо приспособленными к возделыванию в условиях климата нашей страны, имеющими хорошие биохимические показатели семян в технической спелости (содержание углеводов в гибридах сахарной кукурузы - до $6,5 \%$, водорастворимых полисахаридов - до $6 \%$, а у сверхсахарной кукурузы содержание углеводов - до 7,5 \%, водорастворимых полисахаридов - до 4,8-5,0 \%). В 2015 г. проведено предварительное испытание новых 59 гибридов сверхсахарной кукурузы с участием 22 родительских линий на основе мутации $\mathrm{su}_{1}$-se. Были проанализированы морфологические особенности, урожайность, устойчивость к основным заболеваниям, биохимический состав и антиоксидант- 
ная активность в семенах полной спелости (см. табл.).

Показатель общей антиоксидантной активности варьировал в испытуемых гибридных комбинациях от 31,8 \% до 60,4 \%, эквивалент хлорогеновой кислоты варьировал в диапазоне 568,41008 мкг/г семян. Лучшими показателями антиоксидантной активности характеризовались гибридные комбинации Св. 290 / CE-396 (60,4 \% и 1008 мкг/г), Св. 255 / СЕ 411 (55,5 \% и 987,9 мкг/г), Св. 270 / CE 402 (54,5\% и 970 мкг/г и Св. 285 / CE-414 (53,1 \% и 884,4 мкг/г), а самое низкое значение общей антиоксидантной активности - у комбинаций Св. 260 / СЕ 397 (31,8 \% и 568,4 мкг/Г), Св. 265 / СЕ 398 (34,3\% и 613,2 мкг/г) и Св. 265 / CE 396 (34,8 \% и 622,6 мкг/г).

Рабочая модель гибридов сахарной кукурузы предусматривает совмещения в пределах одного генотипа высокой и стабильной продуктивности, оптимальной архитектоники растения, высокой массы товарного початка, крупности семян, высокого качества товарной продукции, устойчивости к основным заболеваниям. Мы выделили лучшие гибридные комбинации, которые сочетают высокую антиоксидантную активность с другими хозяйственными признаками. По урожайности и товарному виду початков выделились 22 гибридные комбинации, они превышали стандарт на 5-15\%. Зерновая продуктивность одного растения (при $14 \%$ влажности) у стандартов составила: Билявка - 71,1 г, Маричка $\mathrm{F}_{1}-$ 115,2 , Соло $F_{1}-98,8$ г. Лучшими среди изучаемых гибридов были Св. 248 / СЕ-396, Св. 248 /
CE-398, Св. 250 / CE-415, Св. 270 / CE 396, Св. 270 / СЕ 397 и Св. 285 / CE-414, Св. 255 / СЕ 397, Св. 270 х СЕ 397. Распределение гибридов по длине початков показало, что у 81,8 \% образцов початки были средние по размеру (15-18 см). Однако выявлено длиннопочатковых (19-20 см) 18,2 \%. Наиболее ценными являются последние, к которым в частности относятся Св. 255 / СЕ 396, Св. 255 / СЕ 411. Для сахарной кукурузы важным признаком является толщина початка, ведь образцы с толстым початком имеют повышенную способность удерживать влагу и более эффективно использовать ее для формирования зерна, что обеспечивает засухоустойчивость таких форм. В группу с диаметром початка 4,6-5 см отнесены 8 гибридов, в том числе: Св. 280 / Св. 285, Св. 275 / CE 409, Св. 270 / CE 413, Св. 275 / CE 397.

По признаку количества рядов зерен на початке выгодно отличались гибридные комбинации Св. 255 / CE 397, Св. 255 / CE 402, Св. 275 / CE 402, Св. 280 / Св. 285, Св. 280 / Св. 306, Св. 285 / Св. 402, Св. 290 / Св. 397, Св. 295 / Св. 39 (20-22 ряда).

Признак количества зерен на початке является одним из основных, ведь он обеспечивает индивидуальную продуктивность растения. Наибольшим количеством зерен на початке (более 700 шт.) характеризовались такие гибриды: Св. 250 / CE 402, Св. 250 / CE 414, Св. 255 / CE 397, Св. 255 / CE 402, Св. 275 / CE 402, Св. 285 / Св. 402, что составляет $10,1 \%$ от общего количества изучаемых форм.

\section{Характеристика антиоксидантной активности и основных хозяйственно-ценных признаков} у лучших изучаемых гибридных комбинаций сверхсахарной кукурузы

\begin{tabular}{|c|c|c|c|c|c|c|}
\hline $\begin{array}{c}\text { Гибридная } \\
\text { комбинация }\end{array}$ & $\begin{array}{c}\text { Эквивалент } \\
\text { хлорогено- } \\
\text { вой кислоты, } \\
\text { мкг/г }\end{array}$ & АА, \% & $\begin{array}{c}\text { Продуктив- } \\
\text { ность } 1 \\
\text { р-ния, г }\end{array}$ & $\begin{array}{c}\text { Масса } \\
\text { початка } \\
\text { технической } \\
\text { спелости, г }\end{array}$ & $\begin{array}{c}\text { Масса } \\
1000 \\
\text { семян, г дней } \\
\text { от сходов до } \\
\text { технической } \\
\text { спелости, } \\
\text { шт. }\end{array}$ \\
\hline Св. 290 / СЕ 396 & 1008,0 & 60,4 & 52,2 & 222 & 228 & 79 \\
\hline Св. 255 / СЕ 411 & 987,9 & 55,5 & 51,4 & 253 & 248 & 79 \\
\hline Св. 270 / СЕ 402 & 970,0 & 54,5 & 96,4 & 270 & 216 & 86 \\
\hline Св. 290 / СЕ-395 & 928,4 & 55,7 & 96,4 & 163 & 260 & 79 \\
\hline Св. 275 / СЕ 402 & 908,9 & 51,0 & 98,8 & 200 & 184 & 79 \\
\hline Св. 250 / СЕ 414 & 869,0 & 48,8 & 76,9 & 256 & 228 & 77 \\
\hline Св. 290 / Св. 280 & 853,1 & 51,2 & 51,1 & 150 & 256 & 85 \\
\hline Св. 265 / СЕ 411 & 850,2 & 47,7 & 97,7 & 164 & 280 & 79 \\
\hline Св. 255 / СЕ 397 & 831,5 & 46,7 & 109,2 & 249 & 236 & 77 \\
\hline Св. 295 / СЕ 398 & 826,2 & 49,6 & 46,2 & 242 & 196 & 79 \\
\hline Св. 255 / СЕ 396 & 820,5 & 46,0 & 108,2 & 254 & 260 & 77 \\
\hline
\end{tabular}

Важным элементом в структуре продуктивности является масса 1000 зерен. Выделено 8 гиб- 


\section{СІЛЬСЬКЕ ГОСПОДАРСТВО. РОСЛИННИЦТВО}

ридов с массой 1000 зерен более 250 грамм. Лучшие из них: Св. 255 / СЕ 396, Св. 265 / СЕ 411, Св. 280 / Св. 285, Св. 298 / Св. 295, Св. 290 / Св. 395 и другие.

В ряде изученных образцов высокая антиоксидантная активность сочетается с комплексом хозяйственно-ценных признаков:

- Св. 285 / Св. 414 - среднеспелый (от всходов до технической спелости 74 дня), высокорослый (высота растения 250 см), высокопродуктивный (зерновая продуктивность растения $14 \%$ влажности 110 г). На растении 1,5 початка. Початок средний (18 см) слабо цилиндрической формы. Количество рядов зерен - 18. Количество зерен на початке высокое (650 шт.). Зерно светложелтое, крупное (масса 1000 зерен 236 г). Початок технической спелости крупный (240 г), толстый (диаметр в средней части 4,5 см). Результаты дегустации свежих вареных початков по пятибалльной шкале -5 .

- Св. 270 / СЕ 402 - среднеспелый (от сходов до технической спелости 72 дня), высокорослый (высота растения 250 см), высокопродуктивный (зерновая продуктивность растения $14 \%$ влажности 96 г). Початок средний (17 см) слабо цилиндрической формы. Количество рядов зерен 22 штук. Количество зерен на початке высокое (770 шт.). Зерно светло-желтое, среднее (масса

\section{БИБЛИОГРАФИЯ}

1. Доспехов Б. А. Методика полевого опыта / Б. А. Доспехов. - М. : Агропромиздат, 1985. $351 \mathrm{c}$.

2. Методичні рекомендації польового та лабораторного вивчення генетичних ресурсів кукурудзи / [підг. І. А. Гур'єва, В. К. Рябчун та ін.]. Харків, 1995. - 29 с.

3. Advanced Separation Method of Food Anthocyanins, Isoflavones and Flavonols / [Valls J., Millan S., Marti M. P., Borras E., Arola L.] // J. Chromatogr. A. - 2009. - Vol. 1216, №43. - P. 71437172 .

4. Analysis of antioxidant-rich phytochemicals / [edited by $\mathrm{Z}$. Xu and L. R. Howard] // WileyBlackwell. - 2012. - 391 p.

5. Antioxidant supplementation decreases oxidative DNA damage in human lymphocytes / [Duthie S. J., Ma A., Ross M. A., Collins A. R.] // Cancer Res. 1996. - Vol. 56. - P. 1291-1295.

6. Arabshahi-Deloue S. Antioxidant Properties of Various Solvent Extracts of Mulberry (Morus indica L.) Leaves / S. Arabshahi-Deloue, A. Urooj // Food Chem. - 2007. - Vol. 102. - P. 1233-1240.

7. Arnao M. B. The hydrophilic and lipophilic contribution to total antioxidant activity / M. B. Ar-
1000 зерен 216 г). Початок технической спелости крупный (240 г), толстый (диаметр в средней части 4,9 см). Результаты дегустации свежих вареных початков по пятибалльной шкале -5 .

Эти гибриды имеют универсальное назначение и могут использоваться для получения как свежей, так и консервированной продукции, отличаются хорошими вкусовыми качествами, обеспечивают урожай до 120-130 ц/га товарной продукции.

Вывод. Значения общей антиоксидантной активности среди проанализированных нами образцов кукурузы варьировали в достаточно широких пределах (от 31,8 \% до 60,4 \%, 568,4-1008 мкг/г семян), что дает нам основание использовать этот показатель в дальнейшей селекционной работе при отборе исходных родительских форм и полученных гибридных комбинаций для повышения антиоксидантных свойств гибридов сверхсахарной кукурузы.

У ряда изучаемых образцов высокая антиоксидантная активность сочетается с повышенным значением отдельных хозяйстенно-ценных признаков или их комплексом, что позволяет рекомендовать данные формы в качестве исходного материала для создания высокопродуктивных гибридов сверхсахарной кукурузы с ярко выраженными антиоксидантными свойствами.

nao, A. Cano, M. Acosta // Food Chem. - 2001. Vol. 73. - P. 239-244.

8. Aruoma O. I. Free radicals / O. I. Aruoma // J. Am. Oil Chem. - 1998. - Vol. 75. - P. 199-212.

9. Block $G$. Fruit, vegetables and cancer prevention: a review of epidemiological evidence / Block G., Patterson B., Sauber A. // Nutrition and Cancer. - 1992. - Vol. 18. - P. 1-29.

10. Basic Biochemical Mechanisms behind the Health Benefits of Polyphenols / [Fraga C. G., Galleano M., Verstraeten S. V., Oteiza P. I.] // Mol. Aspects Med. - 2010. - Vol. 31, №6. - P. 435-445.

11. Boudet A. M. Evolution and Current Status of Research in Phenolic Compounds / A. M. Boudet // Phytochemistry. - 2007. - Vol. 68. - P. 2722-2735.

12. Carotenoids: Actual Knowledge on Food Sources, Intakes, Stability and Bioavailability and Their Protective Role in Humans / [Maiani G., Kaston M. J. P., Catasta G. et al.] // Mol. Nutr. Food Res. - 2009. - Vol. 53, Supp 1. 2. - P. S194-S218.

13. Crozier A. Bioavailability of Dietary Flavonoids and Phenolic Compounds / A. Crozier, D. Del Rio, M. N. Clifford // Mol. Aspects Med. - 2010. Vol. 31, №6. - P. 446-467.

14. Does Wine Consumption Explain the French 
Paradox? / [De Leiris J., Boucher F., Ducimetiere P., Holdsworth M.] // Dialog. Cardiovasc. Med. - 2008. Vol. 13, №3. - P. 183-192.

15. Dykes L. Phenolic Compounds in Cereal Grains and Their Health Benefits / L. Dykes, L. W. Rooney // Cereal Foods World. - 2007. Vol. 52, №3. - P. 105-111.

16. Estuo N. Assessment of antioxidant capacity in vitro and in vivo / N. Estuo // Free Rad. Biol. Med. - 2010. - Vol. 49. - P. 50-515.

17. Grassmann J. Plant's defence mechanism and its benefits for animals and medicine: role of phenolics and terpenoids in avoiding oxygen stress / J. Grassmann, S. Hippeli, E. F. Elstre // Plant Physiology and Biochemistry. - 2002. - Vol. 40. P. 471-478.

18. Halliwell B. Free Radicals in Biology and Medicine : [2 ${ }^{\text {nd }}$ Ed.] / Halliwell B., Gutteridge J. M. C. - Oxford : Clarendon Press, 1989.

19. Leopoldini M. The Molecular Basis of Working Mechanism of Natural Polyphenolic Antioxidants / M. Leopoldini, N. Russo, M. Toscano // Food
Chem. - 2011. - Vol. 125, №2. - P. 288-306.

20. Martin K. R. Polyphenols as Dietary Supplements. A Double-Edged Sword / K. R. Martin, C. L. Appel // Nutr. Dietary Suppl. - 2010. - Vol. 2. P. 1-12.

21. Ou B. Development and validation of an improved oxygen radical absorbance capacity assay using fluorescein as the fluorescent probe / B. Ou, M. Hampsch-Woodill, R. L. Prior // J. Agric. Food Chem. - 2001. - Vol. 49. - P. 4619-4626.

22. Phenolic Compounds in Brassica Vegetables / [Cartea M. E., Francisco M., Soengas P., Velasco P.] // Molecules. - 2011. - Vol. 16. - P. 251-280.

23. Plant Polyphenols: Chemical Properties, Biological Activities and Synthesis / [Quideau S., Deffieux D., Douat-Casassus C., Pouysegu L.] // Angew. Chem. Int. Ed. - 2011. - Vol. 50, №3. P. 586-621.

24. Wallace T. C. Anthocyanins in Cardiovascular Disease / T. C. Wallace // Adv. Nutr. - 2011. Vol. 2. - P. 1-7. 